\title{
PENGARUH CAMPURAN SERAT PISANG TERHADAP BETON
}

\author{
Sheila Hani ${ }^{1}$, Rini ${ }^{2}$ \\ 1,2Dosen Pengajar Program Studi Teknik Sipil, Fakultas Teknik, UPMI, Medan \\ 1Surel : sheilahani87@gmail.com
}

Diterima : 21 Mei 2018; Disetujui : 28 Mei 2018

\begin{abstract}
ABSTRAK
Beton merupakan salah satu bahan yang sering digunakan untuk pembangunan struktur bangunan, jembatan dan lain-lain. Beton terdiri dari campuran agregat halus (pasir), agregat kasar (kerikil), air, dan semen. Selain bahan tersebut, beton biasanya juga dicampur dengan bahan tambahan. Dalam penelitian ini digunakan serat batang pisang batu sebagai bahan tambahan dalam campuran beton.

Penelitian ini bertujuan untuk mengetahui komposisi campuran serat batang pisang dalam beton, serta mengetahui perilaku keretakan beton saat dilakukan pengujian setelah adanya tambahan serat batang pisang pada campuran beton.

Metode yang digunakan adalah metode eksperimental dengan variasi serat batang pohon pisang, yaitu $0 \%$ (beton normal); $2,5 \%$ dan $5 \%$. Serat pisang dari batang pohon dikeringkan dan dipotong dengan panjang $5 \mathrm{~cm}$ dan ketebalan $3 \mathrm{~mm}$. Dalam pengujian ini digunakan dua model benda uji, yaitu benda uji silinder berukuran $15 \times 30 \mathrm{~cm}$ dan model pelat berukuran 100x100x10 cm. Pengujian yang dilakukan adalah kuat tekan beton yang dilakukan setelah beton mencapai umur 14 dan 28 hari dan pengujian susut yang dapat dilihat secara visual. Dari hasil pengujian secara visual dapat dilihat bahwa benda uji 3 yaitu beton dengan kandungan pisang 5\% memiliki retak yang sangat halus dibandingkan dengan benda uji $2(2,5 \%)$ dan dan benda uji $1(0 \%)$. Untuk pengujian kuat tekan, benda uji 3 memberikan nilai $105 \mathrm{Mpa}$, benda uji $2164 \mathrm{Mpa}$ dan Benda uji $1320 \mathrm{Mpa}$. Hasil kuat tekan berbanding terbalik dengan kemampuan menahan retak. Maka dapat disimpulkan bahwa penambahan serat pisang mengurangi kuat tekan beton namun menambah kemampuan beton menahan keretakan yang terjadi.
\end{abstract}

Kata Kunci : Beton, Kuat Tekan, Serat Pisang

\begin{abstract}
Concrete was one of material which often used in building construction, bridge and others. Concrete was a combination of sand, coarse, water and cement. Beside those material, concrete also mixed with additive. In this research, banana trunk fiber were added as a additive mixture. This study was aimed to get the composition of banana trunk fiber mix, and also to know the crack behavior during compression test and shrunk.

Experimental method were used with variated banana trunk fiber divided into three percentage, 0\%; 2,5\% and 5\%. Banana trunk fiber made from skin of banana trunk tree which dried and cut into $5 \mathrm{~cm}$ length and $3 \mathrm{~mm}$ thickness. In this experiment, two mold concrete models were used. They were silinder mold with size $15 \times 30 \mathrm{~cm}$ and plate size 100x100x10 cm. the compressive test were held after they reach 14 and 28 days and after that day, we could see the shrunk visually. As visual, we could see that sample 3 with 5\% banana trunk fiber had finer crack than sample 2 with 2,5\% banana trunk fiber, and sample 2 had finer crack than sample 1 without addictive. The result of compressive strength for sample 3 was 105 Mpa, for sample 2 was 164 Mpa and for sample 1 was $320 \mathrm{Mpa}$. Compressive strength result was inversely to crack resistance. It concluded that the addition of banana trunk fiber could reduce compressive strength, but could raise the concrete ability in crack resistance
\end{abstract}

Keywords: Concrete, Compressive Strength, Banana Trunk Fiber 


\section{1) Pendahuluan}

Beton merupakan salah satu material konstruksi yang digunakan pada bangunan gedung, jembatan, jalan dan lain-lain. Beton terdiri dari campuran agregat halus (pasir), agregat kasar (kerikil), air, dan semen. Campuran tersebut akan mengeras disebabkan peristiwa reaksi kimia antara semen dengan air. Perbandingan jumlah bahan mempengaruhi kuat tekan beton yang diuji pada standar umur 28 hari. Berdasarkan kuat tekannya beton dibagi menjadi tiga klasifikasi, yaitu beton normal dengan kekuatan tekan kurang dari 50 Mpa, beton kinerja tinggi dengan kekuatan tekan antara 50 hingga $90 \mathrm{Mpa}$, beton kinerja sangat tinggi dengan kekuatan tekan lebih dari 90 Mpa. Salah satu sifat penting dari beton adalah daktilitas. Daktilitas beton yang rendah dicerminkan oleh kurva tegangan regangannya yang memiliki penurunan kekuatan tekan yang cepat pada daerah beban pasca puncak, sehingga menyebabkan secara relatif keruntuhan terjadi tiba-tiba.

Untuk mendapatkan sifat - sifat beton yang lebih baik, banyak hal dapat dilakukan. Mulai dari peningkatan mutu material beton sampai dengan memasukkan zat adiktif. Zat adiktif dapat berupa cairan maupun serat. Hasil tes menunjukkan kekuatan tekan beton yang berkurang ketika diberi penambahan serat pisang/rami, namun hasil kelenturan menunjukkan dengan adanya serat pisang/rami, penggunaan agregat kasar dapat dikurangi dan aliran panas pada beton juga berkurang (Ellie Awwad, 2012). Penambahan serat yang mempunyai modulus elastisitas yang lebih rendah dari modulus elastisitas matrik beton diharapkan dapat membuat beton lebih daktail. Berdasarkan hasil riset Maries Idicula (April 2009), tidak hanya sifat daktail, namun campuran serat batang pisang yang dibebani juga memperlihatkan perilaku positif dari kekuatan tarik, kekuatan lentur dan modulus lentur. Terlebih jika campuran serat batang pisang dibandingkan dengan campuran serat tanaman sisal dengan perbandingan volume yang sama.

Dikatakan bahwa penambahan serat pisang dapat menambah kuat tarik campuran beton serat pisang. Tidak hanya sampai disitu, ketika beton campuran serat pisang tersebut dipanaskan secara bertahap dengan panas sampai $100^{\circ} \mathrm{C}$, material tersebut mengalami peningkatan kekuatan tarik karena telah mencapai glass transtition temperature (Suwanto, 2007). Untuk mendapatkan kuat Tarik yang maksimum, serat pisang yang digunakan juga memiliki panjang ideal. Hasil penelitian A. Elaya Perumal (2011) menyimpulkan bahwa panjang ideal serat pisang dalam suatu beton adalah $15 \mathrm{~cm}$.

Pernyataan mendukung tentang serat pisang juga disampaikan oleh C. Udayana Kiran (2007). Penelitian dilakukan terhadap beberapa jenis serat tanaman, yaitu serat pisang, serat rami matahari dan serat sisal. Dimana hasil menunjukkan bahwa kuat tarik secara umum bertambah, dengan persentase penambahan yang berbeda untuk ketiga jenis serat. Sehingga dapat disimpulkan bahwa kondisi geografi mempengaruhi sifat mekanis masing-masing tanaman.

\section{Kajian Pustaka}

Beton merupakan suatu campuran yang berisi pasir, krikil,air dan semen yang dicampur menjadi satu dengan yang membentuk suatu masa yang sangat mirip seperti batu. beton dapat digunakan untuk membuat pondasi, balok, kolom, dan lain-lain

\subsection{Semen}

Semen yang digunakan dalam bahan beton adalah semen jenis potland karena semen jenis ini merupakan bahan pengikat yang berfungsi untuk mengikat agregat halus dan agregat kasar dengan air dalam suatu adukan. Semen potland yang berkualitas harus memenuhi syarat yaitu:

a. Semen tidak kadaluwarsa, Semen yang kedaluarsa dapat diperiksa dengan cara dipegang oleh tangan, bila masih hangat, maka semen belum kadaluwarsa.

b. Semen belum mulai menggumpal. Semen yang sudah ditimbun terlalu lama maka akan menjadi bergumpal, semen yang baik adalah semen yang ditimbun tidak lebih dari 1bulan dengan sistem penyimpanan menggunakan alas dan tidak boleh lebih dari 10 tumpukan semen.

c. Semen masih bereaksi, semen yang baik yaitu semen yang belum mulai menggumpal dan apabila digenggam dengan tangan maka akan jatuh berhamburan.

\subsection{Agregat}

Agregat adalah butiran mineral yang berfungsi sebagai bahan pengisi dalam campuran mortar (aduk) dan beton. Agregat aduk dalam beton dapat juga didefinisikan 
sebagai bahan yang dipakai sebagai pengisi atau pengkurus, dipakai bersama dengan bahan perekat, dan membentuk suatu massa yang keras, padat bersatu yang disebut adukan beton

\subsection{Air}

Air merupakan bahan yang penting pada beton yang menyebabkan terjadinya reaksi kimia dengan semen. Pada dasarnya air yang layak diminum, dapat dipakai untuk campuran beton. Akan tetapi dalam pelaksanaan banyak air tidak layak untuk diminum memuaskan dipakai untuk campuran beton. Apabila terjadi keraguan akan kualitas air untuk campuran beton sebaiknya dilakukan pengujian kualitas air diadakan trial mix untuk campuran dengan menggunakan air tersebut.

\subsection{Bahan Tambah}

Bahan tambahan untuk betonbahan tambah untuk beton (concrete edmixture) adalah bahan ditambahkan di dalam adukan beton pada tahap mula-mula sewaktu beton masih segar. Bahan tambah dapat berupa bahan tambah kimiawi dan bahan tambah mineral. Tujuan penggunaan bahan tambah untuk beton (admixture) secara umum adalah untuk memperoleh sifat-sifat beton yang diinginkan, sesuai dengan tujuan atau keperluannya.

Sifat-sifat beton yang dapat diperbaiki antara lain:

a. Memperbaiki kelecakan beton segar.

b. Mengatur faktor air semen pada beton segar

c. Mengurangi penggunaan semen

d. Mencegah terjadinnya segregasi dan blending

e. Mengatur waktu pengikatan aduk beton

f. Meningkatkan kuat desak beton keras

g. Meningkatkan sifat tahan lama pada beton keras. Sifat tahan lama dapat berhubungan dengan tahan terhadap pengaruh zat kimia, tahan terhadap gesekan, dan sebagainya.

h. meningkatkan sifat kedap air pada beton keras

\subsection{Serat Pohon Pisang}

Tanaman pisang merupakan tanaman yang banyak tumbuh di daerah tropis. Indonesia menjadi salah satu negara di daerah tropis yang memiliki keragaman jenis tanaman pisang.Tanaman ini termasuk dalam jenis annual crops, yaitu kelompok tanaman yang siklus hidupmyahanya semusim atau sekali berbuah Buah dari tanaman pisang memiliki kandungan vitamin A, B dan unsur karbohidrat yang tinggi. Besarnya manfaat dan nilai guna dari buah pisang ini sehingga permintaan serta tingkat konsumsi di masyarakat sangat tinggi. Selain buahnya, daun menjadi bagian tanaman pisang yang sering dimanfaatkan oleh masyarakat. Namun dari keseluruhan sebuah tanaman pisang, batang tanaman menjadi bagian yang belum dimanfaatkan dengan baik. Batang tanaman pisang yang tidak terpakai menjadi sampah dan hingga kini belum terdapat penanganan dan teknologi sederhana yang digunakan untuk mendaur ulang bahan ini. Batang tanaman pisang memiliki susunan yang berlapis dari bagian muda di dalam hingga bagian yang tua di bagian luar. Disamping berlapis, batang tanaman pisang memiliki susunan serat-serat yang halus. Serat dapat diperoleh dari batang tanaman pisang yang telah tua atau batang dengan kandungan air yang sangat rendah maka serat-serat tersebut dapat teramati dengan baik dan mudah dipisahkan. Tes yang telah dilakukan pada serat pisang, meliputi konten karbon, penyerapan air, konten kelembapan, kuat Tarik, analisa elemen dan analisa kimiawi oleh Justiz Smith (2008).

Batang pisang yang biasa digunakan dalam penelitian berupa serat-serat. Tidak hanya berupa serat, tapi benda uji batang pisang dapat dibentuk menjadi anyaman, kemudian di kompositkan dengan epoxy resin. Hasil penelitian menunjukkan bahwa batang pisang anyaman komposit dengan epoxy resin meningkatkan nilai kuat tarik dan kuat lentur (M. A. Maleque, 2007).

N.Venkateshwaran(2010)menyimpulka $\mathrm{n}$ bahawa campuran serat pisang sebagai bahan tambah dilihat dari sifat struktur, fisik dan mekanis akan lebih diminati. Dikarenakan kerapatannya yang rendah, kuat Tarik yang tinggi, modulus Tarik yang tinggi dan rentangan yang rendah dari serat pisang, campuran dari serat pisang sangat potensial dalam penggunaan sektor yang bervariasi, mulai dari konstruksi, automotif dan lainnya.

\section{Metodologi}

Metode yang digunakan dalam penelitian ini adalah metode kajian eksperimental. Dimana beberapa hal yang perlu dipersiapkan diantaranya: penentuan persentase serat batang pisang sebagai suatu variabel bebas, peralatan yang dipakai, material yang digunakan beserta tahapan penelitian. 


\subsection{Variabel Penelitian}

Dalam penelitian ini diberikan tambahan serat batang pisang batu sebagai variable bebas dengan persentase terhadap volume beton yaitu $0 \% ; 2.5 \% ; 5 \%$. Benda uji terbagi atas dua model, yaitu pelat dengan ukuran $100 \times 100 \mathrm{~cm}$ dan silinder dengan ukuran $15 \times 30 \mathrm{~cm}$. Sedangkan yang menjadi variabel pengendali diantaranya adalah: Tipe semen; Faktor Air Semen; Ukuran Maksimum Agregat; Cara Perawatan Benda Uji serta Umur Benda Uji.

\subsection{Peralatan}

Untuk pembuatan beton campuran serat batang pisang ini digunakan peralatan di laboratorium berupa: timbangan, oven, kompor Listrik, gelas ukur, jangka sorong, ayakan, pelat capping, cetakan beton.

\subsection{Material}

Beton campuran dalam penelitian ini menggunakan material berikut: semen Portland, agregat halus yaitu pasir, agregat kasar yaitu kerikil, air bersih, serat batang pisang batu dengan dengan diameter $3 \mathrm{~mm}$ dan panjang $5 \mathrm{~cm}$. serat pisang dapat dilihat pada Gambar 1 dibawah ini.

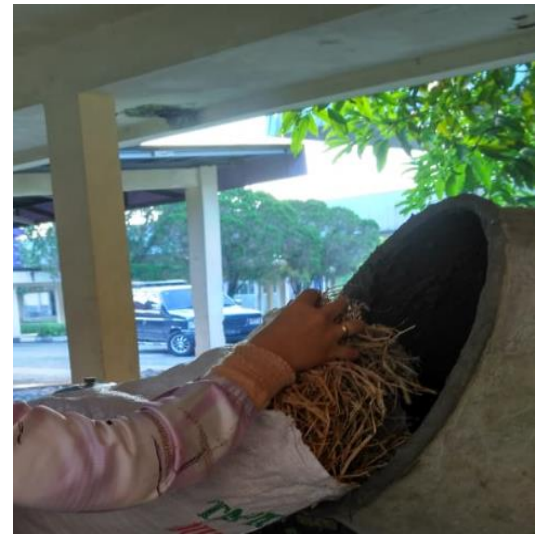

Gambar 1. Serat Pisang Sebagai Bahan Tambah Pada Beton

\subsection{Metode}

Untuk pembuatan beton normal, langkahlangkah pencampuran mengikuti spesfifikasi SNI untuk beton. Dalam penelitian ini digunakan perbandingan komposisi semen:pasir:batu pecah adalah 1:2:3. Serat pisang yang telah mengalami proses pengeringan selama 1 minggu kemudian dicampur kedalam beton dengan persentasi $2,5 \%$ dan $5 \%$ terhadap semen. Kemudian hasil campuran masing -masing variasi dibagi menjadi bentuk silinder sebanyak tiga buah dan bentuk pelat sebanyak satu buah.

\section{Hasil dan Pembahasan}

Hasil yang diperoleh dari penelitian ini yaitu berupa kuat tekan dan keretakan secara visual. Pembahasan dari hasil pengujian adalah sebagai berikut.

\subsection{Keretakan Yang Terjadi}

Untuk melihat retak secara jelas, maka benda uji dibentuk dalam model pelat. Unutk model pelat ini tidak dilkukan uji tekan, namun dilihat keretakan yang ditimbulkan akibat susust yang terjadi. Benda uji 1 (beton normal) menunjukkan keretakan yang lebih besar dibandingkan benda uji 2 (serat pisang 2,5\%). Sedangkan benda uji 2 menunjukkan retak yang lebih besar dari benda uji 3 (serat pisang $5 \%$ ). Semakin banyak kadar serat pisang maka ikatan campuran beton menjadi lebih baik. Hal ini dapat dilihat dari Gambar 2 dibawah ini.

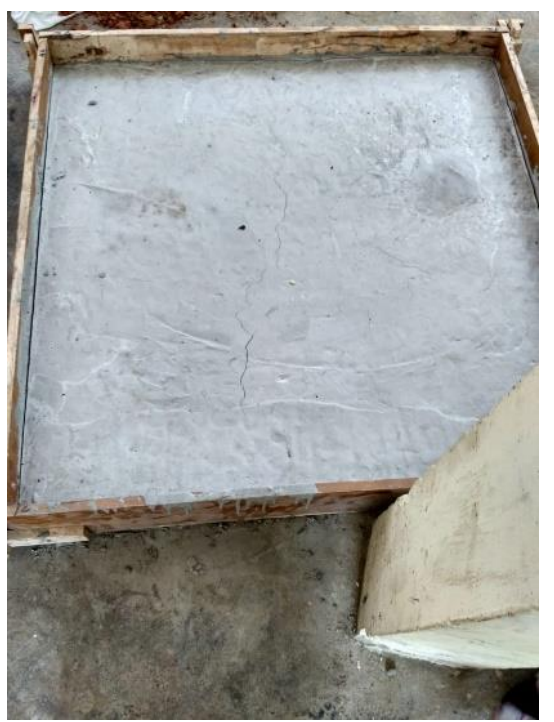

(a)

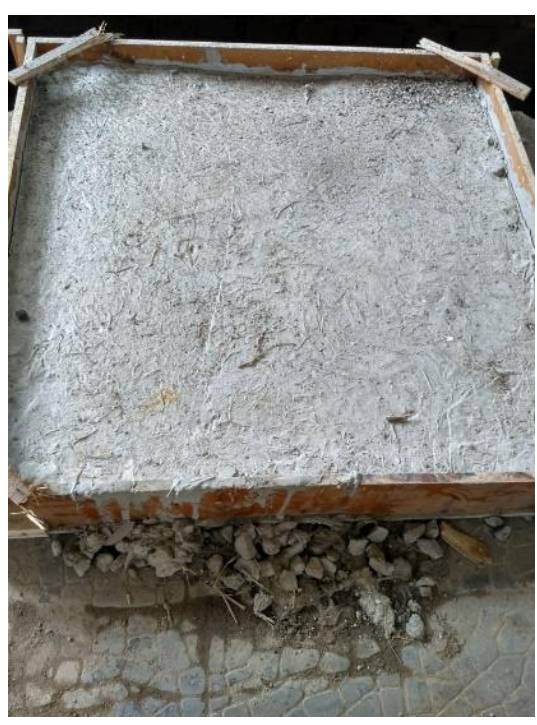

(b) 


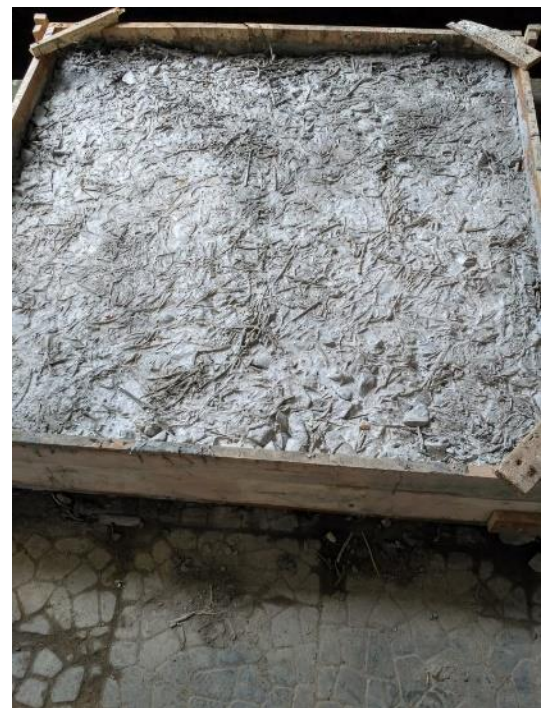

(c)

Gambar 2. (a) Beton Normal-Benda Uji 1 (B)Beton Campuran Serat Pisang 2,5\%-Benda Uji 2 (C)Beton Campuran Serat Pisang 5\%-Benda Uji 3

\subsection{Kuat Tekan}

Beton dengan penambahan serat pisang memiliki kuat tekan yang leih kecil dibandingkan dengan beton normal. Semakin banyak serat pisang yang dicampurkan, maka semakin kecil pula kuat tekan beton campuran tersebut. Hasil kuat tekan beton dapat dilihat pada Tabel 1 berikut ini.

Tabel 1. Kuat Tekan Beton

\begin{tabular}{llc}
\hline No & Nama Benda Uji & $\begin{array}{c}\text { Beban } \\
\text { Tekan } \\
(\mathbf{k N})\end{array}$ \\
\hline 1 & BU-1 (Normal) & 320 \\
\hline 2 & BU-2 (serat pisang 2,5\%) & 164 \\
\hline 3 & BU-3 (serat pisang 5\%) & 105 \\
\hline
\end{tabular}

\section{Simpulan}

Dari hasil penelitian yang dilakukan terhadap tiga benda uji dengan variasi komposisi serat pisang yang masing - masing terdiri dari dua model cetakan beton, dapat ditarik kesimpulan sebagai berikut:

1) Serat pisang dapat digunakan sebagai campuran beton dengan memperhatikan ukuran dari pemotongan serat. Semakin tipis ukuran pemotongan serat memberikan hasil yang lebih maksimal.

2) Dari hasil tekan beton, kadar serat pisang mempengaruhi kekuatan beton, semakin banyak serat pisang yang ditambahkan, kekuatan beton akan semakin berkurang.
3) Retak yang terjadi akibat susut dapat dilihat dari benda uji dengan model cetakn pelat. Dimana semakin banyak kadar serat pisang yang ditambahkan, maka ikatan beton menjadi lebih kuat sehingga retak yang terjadi semakin kecil

\section{Daftar Pustaka}

Badan Standardisasi Nasional. 1991. Spesifikasi Bahan Tambah Untuk Beton. SNI-032495-1991. Jakarta: Departemen Pekerjaan Umum.

Bhoopati, R., M. Ramesh \& C. Deepa. 2014. Fabrication and property evaluation of banana-hemp-glass fiber reinforced composites. Procedia Engineering, 97, 2032-2041.

Elayapermal, A., N. Venkateshwaren \& M. S. Jagatheeshwran. 2011. Effect of fiber length and fiber content on mechanical properties of banana fiber/epoxy composites. Journal of Reinforced Plastics and Composites, 30(19), 1621-1627.

Ellie A., Mounir M., Bilal H., Mohammad T. F. \& Helmi K (2012). Studies on fiber reinforced concrete using industrial hemp fibers, Elsevier Journal. 35, p.710717.

Idiculla, M., Kuruvilla J. \& Sabu T. 2009. Mechanical Performance of short banana/sisal hybrid reinforced polyester composite. Journal of Reinforced Plastic and Composite.

Justiz-Smith, N. G., Virgo, G. J. and V. E. Buchanan. 2008. Potential of Jamaican Banana, Coir, Bagasse Fiber as Composite Materials. Journal of Material Characterization, 59, 1273-1278.

Maleque, M.A. \& F. Y. Belal. 2007. Mechanical properties study of pseudo-stem banana fiber reinforced epoxy composite. The Arabian Journal for Science and Engineering, 32 (2B).

N. Venkateshwaran and A. Elayaperumal.2010. Banana fiber reinforced polymer composites - a review. Journal of Reinforced Plastics and Composites, 29, 2387.

Ningsih Suprapti. 2012. Pengaruh serbuk serat batang pisang sebagai filler terhadap 
sifat mekanis komposit Pvc - Caco3.

Yogyakarta: Balai Besar Kulit, Karet Dan Plastik.

Udayan Kiran, C., G. R. Reddy, B. M. Dabade \& S. Rajesham. 2007. Tensile properties of sun hemp, banana and sisal fiber reinforced polyester composites. Journal of Reinforced plastics and composites, 26(10). 